\title{
Short communication: Sensory profile of raw goat milk cheeses made with artisan kid rennet pastes from commercial-weight animals: Alternative to farmhouse goat cheeses
}

\author{
M. Fresno, ${ }^{* 1}$ S. Álvarez, ${ }^{*}$ E. Díaz, ${ }^{*} M$. Virto, $†$ and M. de Renobales $†$ \\ ${ }^{*}$ Animal Production and Forage Research Unit, Canarian Agronomic Research Institute (ICIA), 38200 La Laguna, Spain \\ †Biochemistry and Molecular Biology, Faculty of Pharmacy, University of the Basque Country/EHU, 01006 Vitoria-Gasteiz, Spain
}

\section{ABSTRACT}

The loss of traditional kid rennet pastes in the Canary Islands (Spain), as in many other regions, is most likely due to the custom of using abomasa from very young animals killed below desirable commercial weight. In addition, the reasonable price of commercial rennets (CR) has resulted in the loss of typical sensory characteristics for most farmhouse raw goat milk cheeses, placing them at a disadvantage when local and international markets are full of different cheeses, often with aggressive marketing strategies. This paper analyzes the sensory characteristics of raw goat milk cheeses made with rennet pastes prepared from commercial kid abomasa in 2 ways: dried while full of ingested milk [full, commercial, artisan kid rennet (FCKR)], or dried after being emptied of ingested milk and refilled with raw goat milk [empty, commercial, artisan kid rennet (ECKR)]. This latter practice allows the use of empty abomasa, or abomasa with grass, soil, and so on. Sensory profiles of cheeses made with FCKR and ECKR rennets were compared with those made with $\mathrm{CR}$ by an expert panel $(\mathrm{n}=7)$. The FCKR and ECKR cheeses had similar sensory profiles. Although scores for FCKR cheeses were somewhat higher than for ECKR cheeses, they were in the range found for traditional cheeses made with rennet prepared with abomasa from very young animals. The sensory profile of CR cheeses was very different. Almost $90 \%$ of consumer panelists ( $\mathrm{n}=$ 90) preferred cheeses made with the experimental rennet pastes. These results demonstrate the possibility to prepare artisan rennet pastes from commercial-weight kids in an easy way for farmhouse cheese makers using local resources that would otherwise be destroyed in abattoirs.

Key words: raw goat milk cheese, artisan kid rennet paste, Canarian goat cheese, sensory characteristic

Received April 15, 2014.

Accepted June 14, 2014.

${ }^{1}$ Corresponding author: mfresno@icia.es

\section{Short Communication}

Cheese is one of the agricultural products of the Canary Islands with a good future; it is not only in demand today but expected to be in high demand in the coming years. During 2010, goat cheese production was 12,250 t, with raw milk cheeses comprising $52.4 \%$. In the Canary Islands, there are about 400 cheese factories, about $89 \%$ of which are small farmhouses, each one producing less than 150 t/yr (Fresno et al., 2012). In the past, all Canarian goat cheese makers traditionally used their own rennets prepared with abomasa from very young animals (killed below commercial weight) according to various local recipes. However, the use of traditional rennets has decreased dramatically in the last 2 decades, probably due to 2 different factors: (1) serious difficulties with reproducing both cutting time and the sensory characteristics of the resulting cheeses and (2) the economic loss of having to kill the animals before reaching commercial weight. Thus, as an example of this situation in the Canary Islands, in 1992, artisan rennets were used in $96 \%$ of Palmero protected designation of origin (PDO) cheeses, $56 \%$ of Majorero PDO cheeses, and $100 \%$ of Gomero cheeses. Another inquiry in 2010 revealed that only $14 \%$ of Palmero, $0 \%$ of Majorero, and 20\% of Gomero farmhouse cheeses still used artisan rennets (Fresno and Álvarez, 2011). Genetically engineered chymosin has now become the rennet of choice (mostly due to its lower price), causing the loss of typical sensory profiles of these traditional cheeses.

Lamb rennet paste from abomasa full of suckling milk contains higher levels of lipase activity than others obtained from empty stomachs (Bustamante et al., 2000; Addis et al., 2008) and cheeses made with these pastes showed higher concentration of short-chain FFA (Virto et al., 2003; Ferrandini et al., 2012) that are correlated with strong sensory attributes described as "pungent," "pecorino," or goat odor or flavor, and intense odor and flavor (Virto et al., 2003). Studies about enzymatic activities of rennet pastes showed that they correlate well with specific quality attributes of tradi- 
tional autochthonous cheeses (Jacob et al., 2011). Thus, harmonizing complex and time-consuming preparation protocols for artisan rennets to be used in farmhouse cheeses is highly desirable to preserve their traditional characteristics. To the best of our knowledge, the sensory characteristics and consumer preferences of raw goat milk cheeses made with artisan kid rennet pastes prepared from commercial-weight kids have not been previously investigated and organoleptic properties are one of the most important criteria in purchasing decisions. Thus, the objectives of this research were to (1) study the sensory characteristics of goat cheeses manufactured with artisan rennets from commercial-weight animals and (2) provide cheese makers with easy-to-use methodology to prepare their own rennets.

Majorera goat kid abomasa (23) were collected from an authorized abattoir from kids with commercial weight at slaughter $(6-8 \mathrm{~kg}$ of liveweight after 45 to $60 \mathrm{~d}$ of age). Kids were separated from their mothers for $12 \mathrm{~h}$ and were then allowed to suckle ad libitum before sacrifice for a maximum of $3 \mathrm{~h}$. All 23 collected abomasa were full of milk. After collection, previsceral fat was removed. Ten abomasa that had a darker color were emptied and refilled with raw goat milk [empty commercial artisan kid rennet (ECKR)]. The 13 remaining abomasa were left full of milk [full commercial artisan kid rennet (FCKR)]. All abomasa were placed in a $5 \% \mathrm{NaCl}$ solution at 4 to $6^{\circ} \mathrm{C}$ for $1 \mathrm{wk}$ and hung to dry to constant weight for approximately $1.5 \mathrm{mo}$ in a dry and dark place at 10 to $15^{\circ} \mathrm{C}$. Empty commercial artisan kids rennet and FCKR dried abomasa were ground separately to a fine paste. Each batch of either type of paste was divided into 2 lots that were stored in screw-capped glass jars at 4 to $6^{\circ} \mathrm{C}$. Microbiological analyses of cheeses were performed as specified in $\mathrm{Eu}-$ ropean Union (EU) Regulation (CE) 1441/2007 (EU, 2007). Coagulation time was determined as described by Berridge (1952).

Before cheesemaking, milk samples were taken in triplicate, and their composition and $\mathrm{pH}$ was analyzed (Álvarez et al., 2007). All cheeses were made in the traditional manner (Fresno and Álvarez, 2007; Sánchez-Macías et al., 2010) by the same cheese master in the pilot plant located at the Instituto Canario de Investigaciones Agrarias (La Laguna, Tenerife, Spain). Immediately before cheesemaking, a given amount of each rennet paste was diluted in water so that clotting would be completed in 30 to $35 \mathrm{~min}$ at $30 \pm 1^{\circ} \mathrm{C}$ in all cases. Experimental cheese fabrications with ECKR, FCKR, and control commercial CHY-MAX rennets (CR; Chr. Hansen SL, Tres Cantos, Spain) were done in triplicate on 2 different days, resulting in a total of 36 cheeses $(3$ types of rennet $\times 2$ different days $\times 2$ cheeses per batch). The only variation factor was the type of rennet, as in all fabrications the amount of rennet was adjusted to give the same coagulation strength.

Proximal cheese chemical composition, $\mathrm{pH}$, and sensory analyses were determined in triplicate (Álvarez et al., 2007). With the same sensory methodology and panel, 4 training sessions were conducted with 14 commercial farmhouse cheeses of about 150 ripening days made with traditional kid rennet (TKR) from very young animals (less than $10 \mathrm{~d}$ of age). These cheeses were a representative sample of all Canarian cheeses made with TKR rennet.

Preference tests were done according to the Spanish Association for Standardisation and Certification standard UNE 87-005-92 (AENOR, 1992), as described by Fresno and Álvarez (2007) with 2 panels: (A) a consumer panel comprising 50 individuals who consume Canarian farmhouse cheese several times a week and (B) a panel composed of 40 farmhouse cheese makers and their families. One sample of each cheese was presented to the panelists for them to choose the sample they preferred by odor and taste, as this overall parameter coordinated well with consumer preference (Caspia et al., 2006). Samples were presented in coded, odorless plastic boxes of the same size and shape. Consumer preference tests were conducted individually. A collaborator presented the 3 samples of the different cheeses to each panelist, who selected the one he or she preferred. Panelists could remove any aftertaste with unsalted crackers, sections of Granny Smith apples, or water with very low level of mineralization. The SPSS software (version 15.0; SPSS Inc., Chicago, IL) was used for statistical processing of the results. A general lineal model was used to establish statistically significant differences among sensory parameters according to the factor "type of rennet" and post hoc multiple analyses by the Tukey test were done. Chi-squared tests were also performed to determine the significance of differences among subjects' consumption preferences and pairwise comparison between artisan kid rennet (FCKR and ECKR) and CR were performed according to tables from UNE 87-005-92.

No statistically significant differences were observed in milk samples. As reported by other authors (Pirisi et al., 2007), no statistically significant differences in proximal composition $(P>0.05)$ were observed among cheeses $(\mathrm{n}=36)$ : fat $=34.87 \pm 1.17 \%$, fat in $\mathrm{DM}=$ $51.23 \pm 1.52 \%$, protein $=21.30 \pm 1.6 \%$, moisture $=$ $31.96 \pm 3.19 \%$, and $\mathrm{pH}=5.17 \pm 0.15$. Microbiological analyses indicated absence of Listeria spp., Salmonella spp., and Staphylococcus aureus for all cheeses [Regulation (CE) 1441/2007]. From a hygienic point of view, all cheeses were fit for human consumption, as reported by Gil et al. (2007) and Moschopoulou (2011), and for cheeses made with artisan rennet pastes. 
Table 1. Sensory characteristics of commercial farmhouse cheeses $(n=14)$ from the Canary Islands made with traditional young goat kid rennet (TKR) as coagulant, and ripened for $150 \mathrm{~d}^{1}$

\begin{tabular}{lccc}
\hline Sensory attribute & Mean $\pm \mathrm{SD}$ & Minimum & Maximum \\
\hline Odor intensity & $4.31 \pm 0.83$ & 3.50 & 6.00 \\
Flavor intensity & $5.35 \pm 0.85$ & 4.00 & 6.50 \\
Rennet odor & $3.23 \pm 0.93$ & 1.00 & 4.50 \\
Rennet aroma & $3.21 \pm 1.05$ & 1.00 & 4.50 \\
Pungent odor & $2.62 \pm 0.85$ & 1.00 & 3.50 \\
Pungent aroma & $2.70 \pm 0.92$ & 1.00 & 3.50 \\
Rancid odor & $2.38 \pm 0.80$ & 1.00 & 3.50 \\
Rancid aroma & $2.60 \pm 1.07$ & 1.00 & 4.00 \\
Pungent in taste & $3.42 \pm 0.95$ & 2.00 & 5.00 \\
Taste persistency & $4.57 \pm 0.68$ & 3.00 & 6.00 \\
\hline
\end{tabular}

${ }^{1}$ Intensity scale (1-7) and sensory descriptors by a trained panel (Álvarez et al., 2007).

The main sensory descriptors of commercial cheeses made with TKR rennets are described in Table 1. Intensity scores for these descriptors range widely, particularly those for "rancid odor," "rennet odor," "rennet aroma," "pungent aroma," and "pungent taste." These descriptors were identified as the traditional cheese profile.

Texture parameters of experimental cheeses (Table 2) were not significantly affected by the type of rennet used, most likely due to the lack of statistically significant differences in gross chemical composition. Ferrandini et al. (2011) showed an increase in instrumental firmness for goat cheese made with lamb rennet associated with a decrease in moisture. The sensory textural profile of FCKR, ECKR, and CR cheeses was similar to that of other Canarian cheeses of the same ripening time (Fresno and Álvarez, 2007). Cheeses were dry, elasticity was low, and roughness was between fine and sandy. In mouth, they were hard, firm, and friable; solubility was between medium and high, and adherence was between weak and medium. Granulosity was very floury. No crunchy sensation was detected.

Cheeses made with FCKR rennet showed significantly higher scores for strong aroma attributes than cheeses made with ECKR or CR rennet (Table 2). Mild attributes such as butter aroma and odor were only detected in cheeses made with ECKR rennets, whereas cheeses made with $\mathrm{CR}$ rennet showed fermented fruit odor and aroma as well as bitterness. The CR cheeses were also more acid than the other 2 types of cheeses. The FCKR and ECKR cheeses had similar sensory profiles, although with different degrees of intensity. Descriptors for FCKR cheeses were in the upper range of intensity scores for traditional TKR cheeses and, thus, FCKR cheeses could be considered "overall strong" cheeses. In contrast, ECKR cheeses could be described as "medium-intensity" cheeses because the intensity scores for descriptors of traditional parameters were in the lower range of intensity scores for TKR cheeses. The higher score for pungent or piquant taste in FCKR cheese is probably due to the presence of pregastric lipase in the rennet paste, as described by other investigators (Bustamante et al., 2000; Pirisi et al., 2007; Addis et al., 2008; Ferrandini et al., 2012). Scores found in all cheeses for rennet odor and aroma are similar to those reported for sheep cheeses made with lamb rennet and analyzed with the same methodology by other authors (Virto et al., 2003; Scintu et al., 2010). It should be clarified that rancid sensations with the reported intensities were not considered negative, but were well evaluated as notes related to old traditional cheeses.

The preference test showed (Table 3) a clear preference for cheeses made with the experimental kid rennet pastes: 88 and $92.5 \%$ of consumers in panels $\mathrm{A}$ and B $(P<0.001)$, respectively. Cheeses made with $\mathrm{CR}$ were clearly the least preferred perhaps due to the poor aromatic profile and their acid and bitter taste.

Comparing cheeses made with artisan pastes (FCKR and ECKR), the age of panel members indicated that young judges chose ECKR, whereas older testers preferred FCKR, especially in panel B (70\%), probably due to the fact that older consumers were more used to the traditional, complex, and strong flavor of these cheeses, although these preferences were not statistically significant according to the reference tables. These results should be very helpful for cheese makers, as they indicate that the flavors related to the use of artisan rennets are appreciated by most consumers, regardless their age. Only 10\% of consumers (mostly younger ones) chose CR cheeses, most likely due to their flat aromatic profile in contrast to the richer and more complex aromatic profile of experimental cheeses. Chi-squared tests indicate that age had a significant effect on cheese preferences in both panels.

Results presented in this manuscript indicate that artisan rennets prepared with abomasa from commercial-weight animals (a clear economic advantage over the current practice of killing excessively young animals) are adequate to produce Canarian-style farmhouse cheeses and other local cheeses with traditional 
Table 2. Sensory characteristics (mean $\pm \mathrm{SD}$ ) of 150 d-old goat raw milk cheeses made with 3 different coagulants ${ }^{1}$

\begin{tabular}{|c|c|c|c|}
\hline \multirow[b]{2}{*}{ Sensory attribute } & \multicolumn{3}{|c|}{ Type of coagulant ${ }^{2}$} \\
\hline & FCKR & ECKR & $\mathrm{CR}$ \\
\hline Odor intensity & $4.71 \pm 0.39^{\mathrm{b}}$ & $3.36 \pm 0.24^{\mathrm{a}}$ & $3.21 \pm 0.57^{\mathrm{a}}$ \\
\hline Aroma intensity & $6.14 \pm 0.38^{\mathrm{b}}$ & $5.79 \pm 0.49^{\mathrm{b}}$ & $3.79 \pm 0.39^{\mathrm{a}}$ \\
\hline Rennet odor & $3.79 \pm 0.49^{\mathrm{c}}$ & $3.00 \pm 0.29^{\mathrm{b}}$ & $0^{\mathrm{a}}$ \\
\hline Rennet aroma & $3.86 \pm 0.56^{\mathrm{c}}$ & $3.00 \pm 0.29^{\mathrm{b}}$ & $0^{\mathrm{a}}$ \\
\hline Pungent odor & $3.14 \pm 0.24^{\mathrm{b}}$ & $1.14 \pm 0.24^{\mathrm{a}}$ & $1.07 \pm 0.19^{\mathrm{a}}$ \\
\hline Pungent aroma & $3.14 \pm 0.24^{\mathrm{b}}$ & $1.29 \pm 0.39^{\mathrm{a}}$ & $1.07 \pm 0.19^{\mathrm{a}}$ \\
\hline Rancid odor & $2.79 \pm 0.39^{\mathrm{c}}$ & $1.93 \pm 0.19^{\mathrm{b}}$ & $1.21 \pm 0.27^{\mathrm{a}}$ \\
\hline Rancid aroma & $3.21 \pm 0.27^{\mathrm{c}}$ & $2.14 \pm 0.38^{\mathrm{b}}$ & $1.14 \pm 0.24^{\mathrm{a}}$ \\
\hline Fermented fruit odor & $0^{\mathrm{a}}$ & $0^{\mathrm{a}}$ & $3.21 \pm 0.27^{\mathrm{b}}$ \\
\hline Fermented fruit aroma & $0^{\mathrm{a}}$ & $0^{\mathrm{a}}$ & $2.64 \pm 0.24^{\mathrm{b}}$ \\
\hline Butter odor & $0^{\mathrm{a}}$ & $1.00 \pm 0.50^{\mathrm{b}}$ & $0^{\mathrm{a}}$ \\
\hline Butter aroma & $0^{\mathrm{a}}$ & $1.21 \pm 0.64^{\mathrm{b}}$ & $0^{\mathrm{a}}$ \\
\hline Bitter & $0^{\mathrm{a}}$ & $0^{\mathrm{a}}$ & $3.07 \pm 0.19^{\mathrm{b}}$ \\
\hline Acidity & $1.29 \pm 0.27^{\mathrm{a}}$ & $1.07 \pm 0.19^{\mathrm{a}}$ & $2.43 \pm 0.45^{\mathrm{b}}$ \\
\hline Pungent in taste & $3.86 \pm 0.38^{\mathrm{c}}$ & $2.14 \pm 0.24^{\mathrm{a}}$ & $3.21 \pm 0.27^{\mathrm{b}}$ \\
\hline Taste persistency & $4.71 \pm 0.57^{\mathrm{a}}$ & $4.29 \pm 0.49^{\mathrm{a}}$ & $4.14 \pm 0.24^{\mathrm{a}}$ \\
\hline Roughness & $3.71 \pm 0.64^{\mathrm{a}}$ & $3.71 \pm 0.27^{\mathrm{a}}$ & $3.71 \pm 0.57^{\mathrm{a}}$ \\
\hline Superficial moisture & $2.07 \pm 0.84^{\mathrm{a}}$ & $2.29 \pm 0.39^{\mathrm{a}}$ & $2.21 \pm 0.76^{\mathrm{a}}$ \\
\hline Elasticity & $1.36 \pm 0.38^{\mathrm{a}}$ & $1.43 \pm 0.34^{\mathrm{a}}$ & $1.57 \pm 0.61^{\mathrm{a}}$ \\
\hline Firmness & $5.24 \pm 0.31^{\mathrm{a}}$ & $5.12 \pm 0.18^{\mathrm{a}}$ & $4.86 \pm 0.38^{\mathrm{a}}$ \\
\hline Friability & $6.00 \pm 0.58^{\mathrm{a}}$ & $5.86 \pm 0.38^{\mathrm{a}}$ & $5.29 \pm 0.64^{\mathrm{a}}$ \\
\hline Adherence & $3.19 \pm 0.28^{\mathrm{a}}$ & $3.16 \pm 0.24^{\mathrm{a}}$ & $3.39 \pm 0.43^{\mathrm{a}}$ \\
\hline Solubility & $4.86 \pm 0.56^{\mathrm{a}}$ & $4.57 \pm 0.45^{\mathrm{a}}$ & $4.36 \pm 0.48^{\mathrm{a}}$ \\
\hline Mouth moisture & $2.07 \pm 0.34^{\mathrm{a}}$ & $2.29 \pm 0.39^{\mathrm{a}}$ & $2.57 \pm 0.45^{\mathrm{a}}$ \\
\hline Granulosity & $3.43 \pm 0.45^{\mathrm{a}}$ & $3.29 \pm 0.27^{\mathrm{a}}$ & $2.86 \pm 0.56^{\mathrm{a}}$ \\
\hline
\end{tabular}

sensory characteristics. The 2 types of rennets used in this study (ECKR and FCKR) allow cheese makers to produce cheeses with similar sensory profiles, but with 2 easily controlled intensities to suit their customers' preferences. The FCKR rennet paste allows using empty abomasa, or abomasa with grass, soil, and so on inside. The use of the traditional coagulants described herein is a useful tool for cheeses with PDO or similar quality labels, as well as for farmhouse cheeses made in developing countries.

\section{ACKNOWLEDGMENTS}

The authors acknowledge support from an ACIISI contract (2009-2010) with FSE funds. Financial support was provided by Cheese Factory Hijos de Vera Montelongo, Quesería LacTindaya (Fuerteventura, Spain), the Instituto Canario de Investigaciones Agrarias (ICIA, La Laguna, Spain), and the GANAFRICA $\mathrm{MAC} / 3 / \mathrm{C} 188$ Project (Canarias-Senegal).

Table 3. Preference test for raw goat milk cheeses made with 3 different coagulants and ripened for $150 \mathrm{~d}$

\begin{tabular}{|c|c|c|c|c|c|c|c|}
\hline \multirow[b]{2}{*}{ Panel $^{1}$} & \multirow[b]{2}{*}{ Age (yr) } & \multirow[b]{2}{*}{ No. } & \multicolumn{3}{|c|}{ Type of coagulant ${ }^{2,3}$} & \multirow[b]{2}{*}{$x^{2}$} & \multirow[b]{2}{*}{$P$-value } \\
\hline & & & FCKR & ECKR & $\mathrm{CR}$ & & \\
\hline \multirow[t]{2}{*}{ A } & $<25$ & 21 & $6(29)$ & $10(48)$ & $5(23)$ & \multirow{2}{*}{18.059} & \multirow{2}{*}{0.001} \\
\hline & $>25$ & 29 & $14(48)$ & $14(48)$ & $1(4)$ & & \\
\hline \multirow[t]{2}{*}{ B } & $<25$ & 13 & $5(38)$ & $6(46)$ & $2(16)$ & \multirow{2}{*}{22.237} & \multirow{2}{*}{0.001} \\
\hline & $>25$ & 27 & $19(70)$ & $7(26)$ & $1(4)$ & & \\
\hline
\end{tabular}

${ }^{1}$ Panel $\mathrm{A}=$ habitual consumers (several times per week) of Canarian farmhouse cheese; panel B: farmhouse cheese makers and their families who produce and regularly consume farmhouse cheeses.

${ }^{2} \mathrm{FCKR}=$ freshly prepared traditional artisan rennet; ECKR $=$ freshly prepared adapted artisan rennet; CR = commercial CHY-MAX rennet (Chr. Hansen SL, Tres Cantos, Spain).

${ }^{3}$ Results are presented as number of consumers (frequency, \%). 


\section{REFERENCES}

Addis, M., G. Piredda, and A. Pirisi. 2008. The use of lamb rennet paste in traditional sheep milk cheese production, 2008. Small Rumin. Res. 79:2-10.

AENOR (Asociación Española de Normalización y Certificación). 1992. Análisis sensorial. Prueba de comparación por parejas. UNE 87-005-92. AENOR, Madrid, Spain.

Álvarez, S., M. Fresno, P. Méndez, N. Castro, J. R. Fernández, and M. R. Sanz Sampelayo. 2007. Alternatives for improving physical, chemical and sensory characteristics of goat cheeses: The use of arid land forages in the diet. J. Dairy Sci. 90:2181-2188.

Berridge, N. J. 1952. Some observations on the determination of the activity of rennet. Analyst (Lond.) 77:57-62.

Bustamante, M., F. Chávarri, A. Santisteban, G. Ceballos, I. Hernández, M. J. Miguélez, I. Aranburu, L. J. R. Barrón, M. Virto, and M. de Renobales. 2000. Coagulating and lipolytic activities of artisanal lamb rennet pastes. J. Dairy Res. 67:393-402.

Caspia, E. L., P. C. Coggins, M. W. Schilling, Y. Yoon, and C. H. White. 2006. The relationship between consumer acceptability and descriptive sensory attributes in Cheddar cheese. J. Sens. Stud. 21:112-127.

EU (European Union). 2007. Reglamento (CE) № 1441/2007 de la Comisión de 5 de diciembre de 2007 que modifica el reglamento (CE) $\mathrm{n}^{\mathrm{Q}}$ 2073/2005 relativo a los criterios microbiológicos aplicables a los productos alimenticios (DOCE de 7/12/2997). European Commission, Brussels, Belgium.

Ferrandini, E., M. Castillo, M. de Renobales, M. D. Virto, M. D. Garrido, S. Rovira, and M. B. López. 2012. Influence of lamb rennet paste on lipolytic and sensory profile of Murcia al Vino cheese. J. Dairy Sci. 95:2788-2796.

Ferrandini, E., M. B. López, M. Castillo, and J. Laencina. 2011. Influence of an artisanal lamb rennet paste on proteolysis and textural properties of Murcia al Vino cheese. Food Chem. 124:583-588.

Fresno, M., and S. Álvarez. 2007. Análisis sensorial de los quesos de cabra de pasta prensada: Queso Majorero DOP y Palmero DOP. Instituto Canario de Investigaciones Agrarias, Santa Cruz de Tenerife, Spain.
Fresno, M., and S. Álvarez. 2011. The relationship between genetic and technological aspects and cheese quality. Pages $43-70$ in Cheese: Types, Nutrition and Consumption. R. D. Foster, ed. Nova Science Publishers, Hauppauge, NY.

Fresno, M., S. Álvarez, A. L. Arteaga, D. T. Benito, M. R. Esparza, F. Fabelo, E. Fernández, E. González, R. González, A. Martínez, E. Monzón, A. Navarrete, A. Rodríguez, and M. E. Camacho. 2012. Caracterización de la producción de queso en las islas canarias (España). Actas Iberoamericanas de Conservación Animal 2:243-247.

Gil, P. F., S. Conde, M. Albisu, F. J. Pérez-Elortondo, I. Etayo, M. Virto, and M. de Renobales. 2007. Hygienic quality of ewes' milk cheese manufactured with artisan-produced lamb rennet pastes. J. Dairy Res. 74:329-335.

Jacob, M., J. Jaros, and H. Rohm. 2011. Recent advances in milk clotting enzymes. Int. J. Dairy Technol. 64:14-33.

Moschopoulou, E. 2011. Characteristics of rennet and other enzymes from small ruminants used in cheese production. Small Rumin. Res. 101:188-195.

Pirisi, A., G. Pinna, M. Addis, G. Piredda, R. Mauriello, S. De Pascale, S. Caira, G. Mamone, P. Ferranti, F. Addeo, and L. Chianese. 2007. Relationship between enzymatic composition of lamb rennet pastes and proteolytic and lipolytic pattern and texture of PDO Fiore Sardo ovine cheese. Int. Dairy J. 17:143-156.

Sánchez-Macías, D., M. Fresno, I. Moreno-Indias, N. Castro, A. Morales-delaNuez, S. Álvarez, and A. Argüello. 2010. Physicochemical analysis of full-fat, reduced-fat, and low-fat artisan-style goat cheese. J. Dairy Sci. 93:3950-3956.

Scintu, M. F., A. del Caro, P. P. Urgeghe, C. Piga, and R. di Salvo. 2010. Sensory profile development for an Italian PDO ewe's milk cheese at two different ripening times. J. Sens. Stud. 25:577-590.

Virto, M, F. Chávarri, M. A. Bustamante, L. J. R. Barron, M. Aramburu, M. S. Vicente, F. J. Pérez-Elortondo, and M. de Renobales. 2003. Lamb rennet paste in ovine cheese manufacture: Lipolysis and flavour. Int. Dairy J. 13:391-399. 